\title{
集合住宅における木製軸組下地による間仕切と 天井の施工性からみた構法特性 \\ THE CONSTRUCTIONAL CHARACTERISTICS OF PARTITIONS AND CEILINGS WITH WOOD BACK-UP STRUCTURES IN APARTMENT HOUSES
}

\author{
王 英 健*, 深 尾 精一** \\ Yingjian WANG and Seiichi FUKAO
}

\begin{abstract}
Through 5 case studies, the constructional characteristics of partitions and ceilings with wood back-up structures in apartments' interior were compared. As results, the following facts have been found: the partition's back-up structure plays a central role in influencing the constructional efficiency of whole interior finish work, the construction method of ceiling's back-up structure is the one which needs improvement urgently, the relation between the Element Density and Man. Minute value of one element in ceiling's back-up structure is inverse proportional, and corresponding movement between partition and ceiling's back-up structures appears in the Han Minute/ $\mathrm{m}^{2}$
\end{abstract}

Keywords:interior finish work, constructability, man-minute, ceiling, partition, wood back-up sturucture

内装、施工性、工数、天井、閻仕切、木製下地軸組

1.はじめに

集合住宅の室内の生活空間を実際に構成する天井、床、 間仕切は、集合住宅の内装における三つの主要素である。 三要素のそれぞれの構法についての適用性（フィージビ リテイー）之相互の適合性（コンパテイビリテイー：間 仕切と天井、床との取合いなど) に関する問題は、集合 住宅の内装を向上させる上での重要な課題である。従来 の大多数の集合住宅の内装は、間仕切と休を主体として おり、天井の大部分は、構造スラブの下面に直接仕上げ 材を貼っていた。集合住宅の住戸に二重天井を全面的に 導入した内装工事は少数例にとどまっていた。しかし、 近年、住生活水準の向上と集合住宅の住戸平面の多様化 によって、集合住宅の内装工事は、間仕切、天井、林を 全面的に用いる例が増えてきている。

間仕切、天井、床構法を完全に併用する場合は、三者 (間仕切、天井、床)がシステムとして統合され、各構法 が適切に調整され、室内施工環境に対して内装構法全体
として適応していることが重要である。現在、一般的に 用いられている各構法、特に天井構法は、今後このまま 使用されるには、以上の点に関し多くの疑問点を抱えて いる。

集合住宅の内装構法に関する既往の研究では、間仕切、 天井、床の三つの棈法のそれぞれについて、様々な調查 が行われている(1)。しかし、現実の集合住宅の内装工事 は、多様な条件下で行われており、棈法の特徴と施工特 性を全体として把握することは容易ではない。その中で も、天井構法については、施工性などの構法特性が明ら かになっていない。間仕切と天井は、下地形状が類似し ているなど、構法面での共通点が多く、施工上の関係も 緊密である。間仕切と天井の施工に関し、問題点を適切 に解明し、施工効率を向上させるためには、両者を同時 に検討対象とする必要がある。

本研究は、現在の集合住宅の内装に最も一般的に使わ れている木製軸組間仕切と天井構法に着目し、二つの構

* 東京都立大学工学部建築学科 大学院生·工修 Graduate Student. Dept. of Architecture, Faculty of Technology,

Tokyo Metropolitan Univ., M. Eng.

** 東京都立大学工学部建築学科 助教授.工博 Associate Prof., Dept. of Architecture, Faculty of Technology, Tokyo Metropolitan Univ., Dr. Eng.
} 


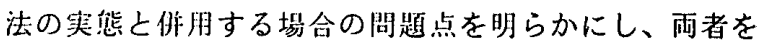
比較検湖することとともに、それらの施工性・施工量及 び相互网係などを把握することにより、二重天井を現状 より広い範围に導入する集合住宅の内装工事を、より合 理化、效倠化する方法を賏き出すための資料を作成する ことを目的としている。

\section{2. 策合住宅の木製軸組間仕切と天井の基本特徵}

現在の集合住宅の内装構法の種類は様々である。その 中で、よく使用されているものは、間仕切、天井の場合 は、木製・金属製（LGS）下地軸組にボード類を張ったも の、床の場合は、発泡スチロール床下地、置休パネル、 木製下地軸組に合板を張ったものなどである。構法の属 性、材質、施工方法などを配慮して、集合住宅の同一住 戸の中に使われる間仕切構法と天井棈法は、同類のもの （例えば、間仕切の下地に木製軸組を用いる時は、同一 住戸の天井下地む木製軸組構法を用いる。）を採用する ことが多い。木製軸組間仕切と天井は、材木の加工のし 易さ、配管・配線・設備機器との取合いの柔軟さ蝮 雑な住戸平面と断面形態への対応などの面でメリットを もち、現在の集合住宅において広範に使用されている。 しかし、二重天井を全面的に張る满法はあまり多くなく、 間仕切との取合い上の問題点は明らかになっていない。 また、間仕切と天井を併用する場合の木製軸組間仕切と 天井棈法の適合性と取合いに関する諸特性や問題点を比 較・把握することは、木製軸組構法だけでなく、L G S 下地など他の内装構法を改良する上でも、重要である。 間仕切と天井の施工は、一般的に、木製軸組下地の施 エとボードの張付の二つの作業で構成される。本研究は、 構法の骨組部分、つまり、木製軸組の施工に焦点を当て ている。

間仕切と天井の相対的な位置関係には、主に間仕切勝 ちと天井勝ちの二種類があるが、間仕切壁と天井の強度、 遮音性、階高、経济性などの配虑の結果、間仕切勝ちが 現在の集合住宅内装の主流となっている。また、下地軸 組を用いた天井を張っている部分がまだ少ないという現 状も、間仕切勝ちを一般的な構法としている。

間仕切勝ちの場合の間仕切、天井の下地軸組の施エプ ロセスと代表的な檴成を図 1 に示した。調查対象の現場 状況、施工者などの違いによって、内装の施エプロセス には多少の相違が存在するが、間仕切の下地軸組の組立 を最初に行うことが一般的である。その次に天井下地軸 組の下地回り縁や床下地の端根太を間仕切の下地軸組、 または、躯体壁に固定して、天井下地軸組の施工を行う。 間仕切、天井のボードを張り付ける工事が完了した以後、 最後に、床の下地パネルを敷設する（休勝ちの場合を除

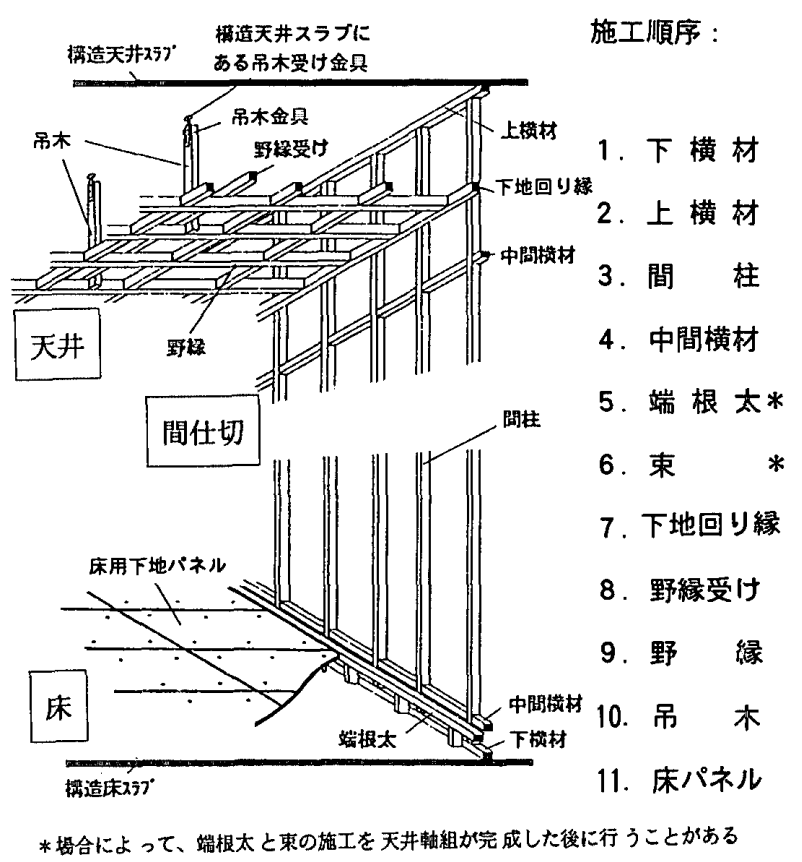

図1間仕切と天井の木製軸組搆法の施エプロセス

( )。

間仕切勝ちの場合の間仕切、天井の木製下地軸組は、 配管・配線・設備機器に対して、主に、軸組の部材配置 方式を変更したり、材木の一部を切る方法、または附加 材を添加する方法で対応している（参考文献1を参照）。

\section{3. 施工性調査の概要}

間仕切及び天井の木製下地軸組の施工実態及び相互の 関係を把握するために、1992年9月10日〜10月15日（調查 I 、II )と 1993年10月13日〜1994年1月15日（調查 III IV、 V) に、四つの集合住宅の建設現場の五つの内装工事(合 計 5 戸)において施工性調查を行った。調查対象は、多摩 ニュータウンに建てられた住宅・都市整備公団の共同住 宅である。それぞれの構造方式は、壁式ラーメン構造

(調查 I )、ラーメン構造(調查 II IV 、 V )、大型 P C a 版壁構造（調査四）である。それらのうち、調查 I、I、

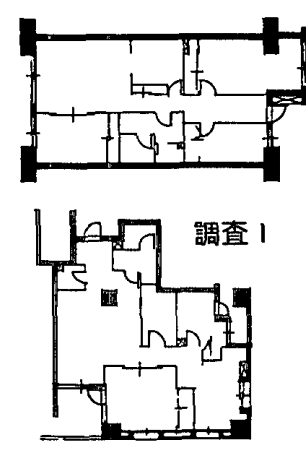

調查 II

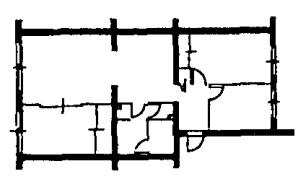

調査 III

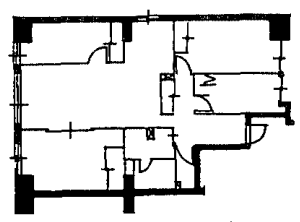

調查IV 調查 V
図 2 調查対象の平面 
III は、3LDK、調查IV、V は同一のプラン（4LDK）で、調 查 Vは最上階住戸であり、ほぼ全面に天井が張られてい る。（図 2 )

施工性調查は、内装（間仕切、天井の下地軸組）の施 エプロセス、間仕切、天井の軸組の製作にかかる工数、 軸組を構成する部材の本数、各部位の施工量などを記録 した。

\section{4. 調査結果と分析}

表 1 は、5つの調查結果の一覧である。なお、本調査研 究では、工数 (人・分) を、職人一人による間仕切、天 井の下地軸組を作成する（床の場合は、下地パネルを政 設する）実作業（軸組を作成する際の採寸、部材加工・ 固定作業等）にかかる時間の累積ととらえている。それ 以外の集中的な部材運搬、部材選択 - 加工、墨出し、及 び現場打ち合わせ、休鄎などの時間は含めていない。調 查は専従調查員が部材ごとに作業を分単位で計測する方 法をとった。

\section{表 1 調查結果一覧}

\begin{tabular}{|c|c|c|c|c|c|c|}
\hline & 調查 I & 調查 II & 調查 III & 調查 $\mathrm{N}$ & 調查 V & 平 均 \\
\hline $\begin{array}{l}\text { 間仕切軸組 部分の } \\
\text { 面皘 }\end{array}$ & 72.40 & 62.70 & 38. 98 & 83. 24 & 83.24 & $\begin{array}{l}\text { 68. } 11 \\
\mathrm{~m}^{\circ}\end{array}$ \\
\hline $\begin{array}{l}\text { 間仕切軸組の構成 } \\
\text { 部材数 }\end{array}$ & 447 & 643 & 348 & 836 & 805 & $\begin{array}{r}615.8 \\
\text { 本 }\end{array}$ \\
\hline $\begin{array}{l}\text { 間仕切軸組 部分の } \\
\text { 工数 }\end{array}$ & 372 & 527 & 348 & 888 & 902 & $\begin{array}{l}607.4 \\
\text { 人.分 }\end{array}$ \\
\hline 天井部分の 面積 * & 11.1 & 9.4 & 11.8 & 12.9 & 40.7 & $\begin{array}{l}17.2 \\
\mathrm{~mm}^{*}\end{array}$ \\
\hline $\begin{array}{l}\text { 天井下地軸組の構 } \\
\text { 成材数 }\end{array}$ & 60 & 63 & 69 & 73 & 202 & $\begin{array}{r}93.4 \\
\text { 本 }\end{array}$ \\
\hline $\begin{array}{l}\text { 天井下地軸組部分 } \\
\text { の工数 }\end{array}$ & 104 & 106 & 108 & 156.5 & 503.5 & $\begin{array}{l}195.6 \\
人 \cdot \text { 分 }\end{array}$ \\
\hline 床面珤＊＊ & 64.54 & 48.07 & 51.47 & 67.93 & 68.15 & $\begin{array}{r}60.03 \\
\mathrm{~m}^{2}\end{array}$ \\
\hline 床下地工数 $* * *$ & 213 & 183 & 190 & 195 & 202 & $\begin{array}{l}196.6 \\
\text { 人. 分 }\end{array}$ \\
\hline
\end{tabular}

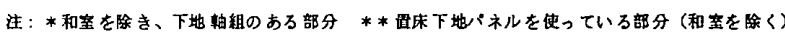
***「**」の筙团内の工效

調查対象の閻訨切、天井、床のそれぞれの施工見付け 耐稓をみると、住戸の中における施工見付け面積は、間 仕切の軌組部分が最も大きく、平均すると下地パネルを 数設する床（和空を除く）の面積の1.1倍である。天非 （下地䡃組のある部分、利室を除く）の施工見付け面程 は、5つの調查侧において、䦌仕切面棈の約 $1 / 4$ 、最上 階の誠查Vを除いた湶合は、諴查I〜IVの合計で間仕切

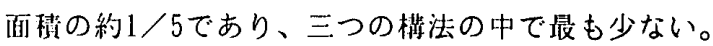

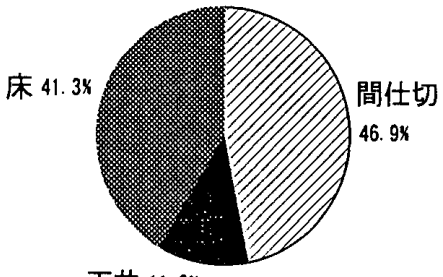

天井 11.8x

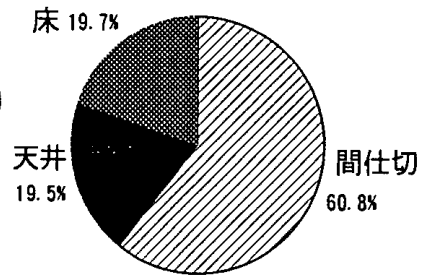

工数
図 3 間仕切、天井の木製軸組と床パネル構法の施工量 と工数の内訳

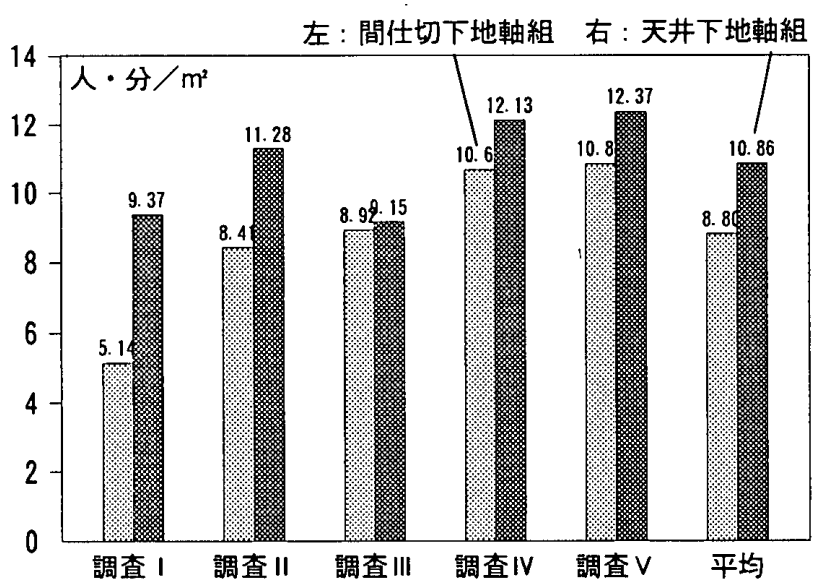

図 4 間仕切と天井の木製軸組の面積当たりの工数

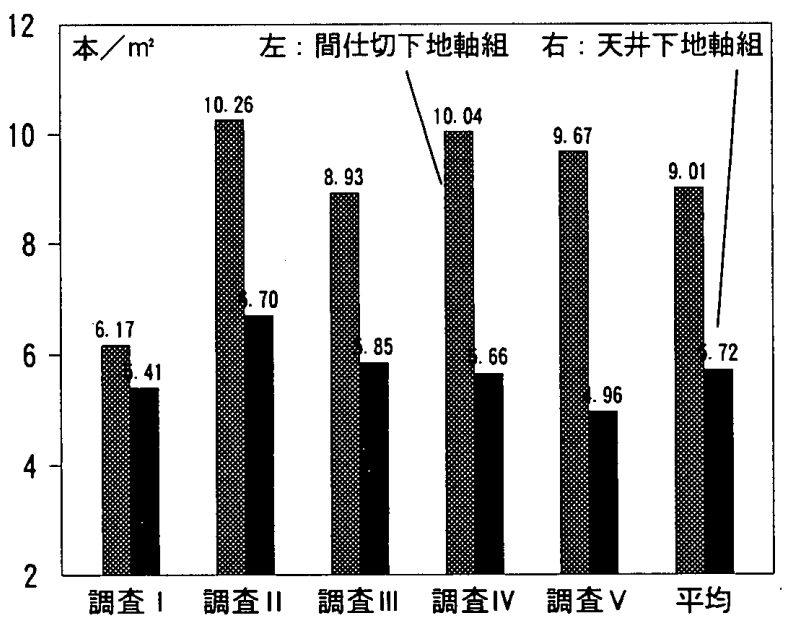

図 5 間仕切と天井の木製軸組の面積当たりの部材本数

5 つの調查例の間仕切、天井のそれぞれの施工にかか る工数をみると、間仕切の軸組部分が最も大きく、三要 素の下地工数の合計の $60.8 \%$ を占めている。天井の下地 軸組部分の工数は全体の $19.5 \%$ を占めているが、調查 I 〜 IV の合計では $14 \%$ である。（図 3 ）

間仕切、天井下地軸組の面積あたり（間仕切壁は施工 見付け面積、天井は下がり天井の垂直部分などを含む施 
工見付け面皘）の工数を比較・検討すると、間仕切軸組 の平均「人・分 $/ \mathrm{m}^{2} 」$ 値は、8.80である。天井下地軸組 の平均「人・分 $/ \mathrm{m}^{2} 」$ 值は、10.86 であり、すべての調 查で、間仕切軸組より高くなっている。また、調查IV と 調查Vはほぼ同じ結果となっている。（図4）

間仕切、天井の下地軸組を構成する線状部材の面積あ たりの本数は、間仕切についてみると、調查口が 10.26

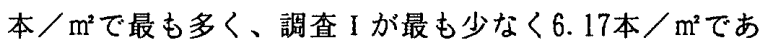
る。このことが施工性の良さにつながっていると考えら れる。5つの調查の全体平均值は、 9.04 本 $/ \mathrm{m}^{2}$ である。

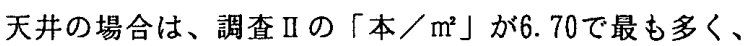
最も少ないのは、調查 Vの4.96であり、全体平均値は、 5. 44本／ $\mathrm{m}^{2}$ である。間仕切と天井の下地軸組を比較する と、間仕切の軸組の部材配置は、天井よりかなり細かい ことが分かった（図 5 ）。さらに、間仕切、天井の軸組 を構成する部材の平均長さを比較すると、間仕划粗組の 全体平均値は $1.06 \mathrm{~m}$ 、天井の全体平均値は、 $1.36 \mathrm{~m}$ で、 上述の軸組を構成する部材密度の傾向（間仕切の俥組の
部材配置は天井より細かいこと）とほぼ一致している。 間仕切の軸組の部材配置は、天井より複雑であることが 明かとなった。

図 6 は、間仕切、天井下地軸組の一本の部材を取り拟 うためにかかる工数を示したものである。天州粙組の場

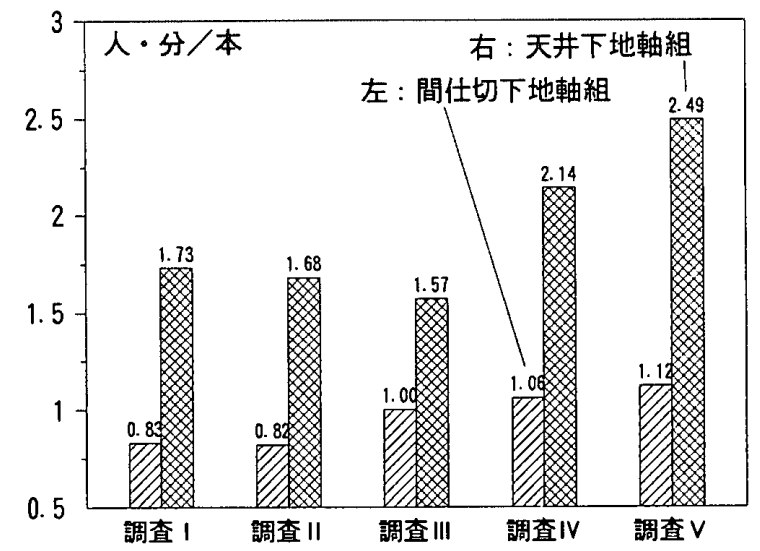

図 6 間仕切と天井の木製軸組の一本の部材を取り扱う ためにかかる工数

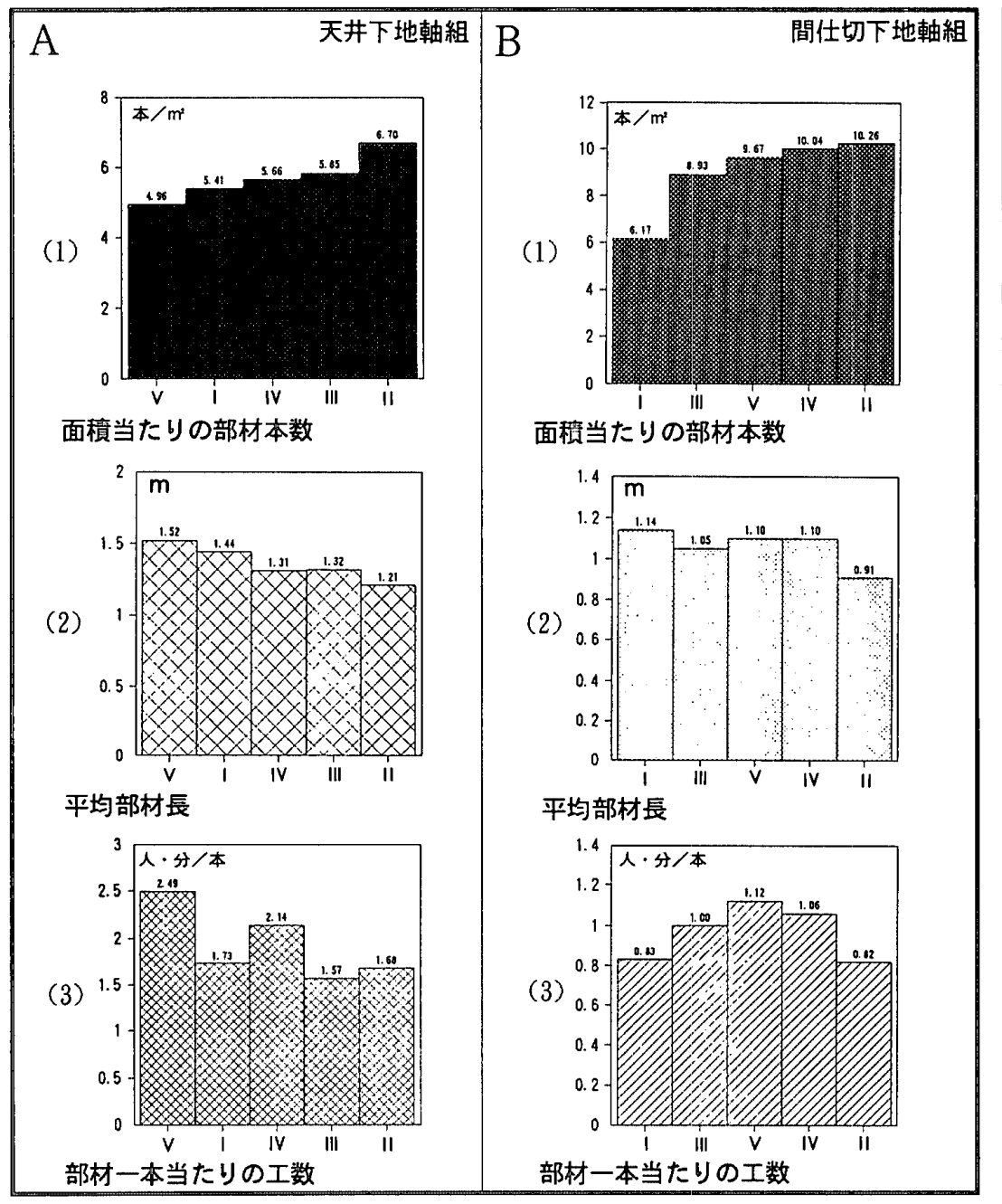

図 7 間仕切と天井朝組の施工特性に関する比較

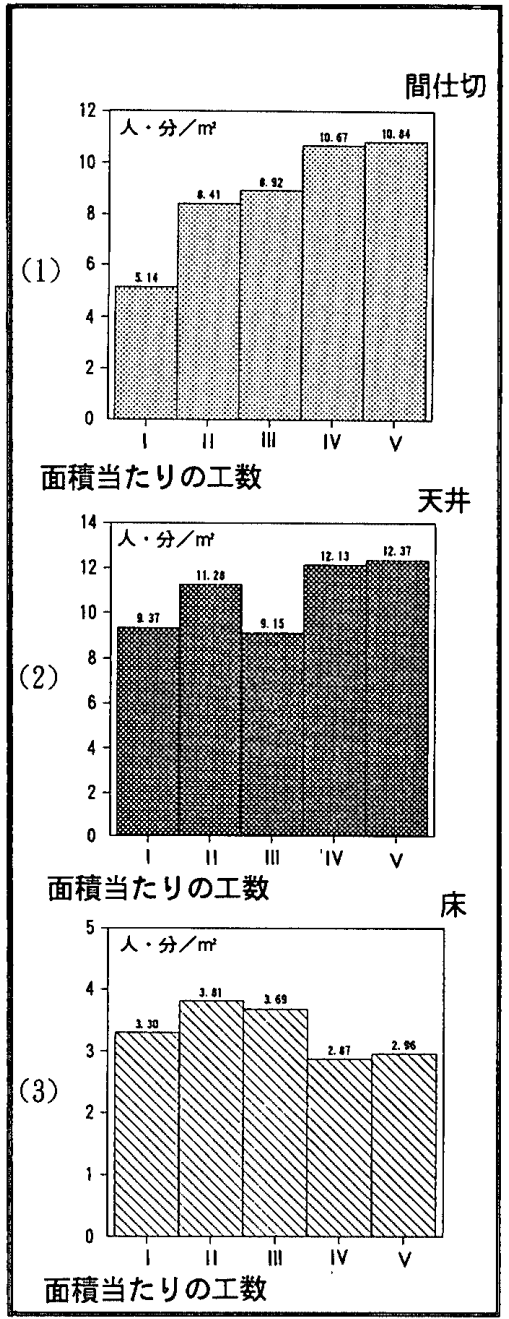

図 8 間仕切、天井軸組と床下地パネ ルの「工数 $\left./ \mathrm{m}^{2}\right\rfloor に$ 関する比較 
合は、平均 1.92 (人・分/本) であり、間仕切糊組の 0.97 (人・分/本) のほほ2 2倍となっており、長さの造 いの比よりはるかに大きくなっている。このことは、天 井軸組の棈成材を取り扱う方法が上向き作滗となること、 部材を保持しながら作業することなどが理由として洘え られる。

図 7 のの( 1 )は、5つの調查例の天井軸組の面積当た りの部材本数を密度順に並へたもの、Aの $(2)$ は、その 順序で天井軸組の平均部材長さを示したものである。A の(1)と(2)を比較すると、天井軸組の部材密度が高くな ると、軸組を構成する部材の平均長さが短くなることが 分かる（ここでいう軸組棈成材の平均長さは、軸組を構 成する線状部材長さの算術平均値である。軸組を構成す る各部材長さの分布については、図9を参照)。Aの(3) の一本の部材の施工にかかる工数は、（1）の部材密度と ほぼ逆の傾向を示しており、これらの結果は、天井の面 積当たりの部材本数を減らすことは工数の削減にはつな がらないことを示している。間仕切についても、同様に、 軸組の部材密度と部材平均長さについて図 7 の Bに示し た。（1）の軸組の面積当たり部材本数と（3）の「工数／ 本」との間には、Aの（1)と（3)のような関係が見られ ない。これらのことは、天井軸組と間仕切軸組それぞれ の施工特性を反映するとともに、現行の天井軸組の施工 においては「長い部材を取り扱うことが短い部材より困 難であること」を示している。

図 8 の( 1 )は、5つの調查例の間仕切軸組の平米あた りの工数を順に並へたもので、図 8 の(2)は、同じ順に 天井軸組の面積あたり工数を示したものである。間仕切 の施工性と天井の施工性には、ある程度、連動する傾向 がみられる。ここで、参考として、同じ順番の床下地パ ネルの面積あたり工数值（図 8 の(3))を(1)、（2）の図と 対照すると、林は、間仕切、天井工事が完了した後、間 仕切、天井の施工者と異なる職人による行われる独立し た工事であることが反映されている。同一住戸の内装工 事において、間仕切と天井の施工速度が同じ傾向を示す という結果は、同一住戸内の間仕切、天井軸組工事の施 工者が同一であり、施工者の技能レベルからの影響が同 じ程度であることが一因であろう。間仕切、天井軸組の 構成方式が住戸ごとにほぼ同じであることも影留してい ると考えられる。

図 10 は、間仕切の木製下地軸組の組立から天井軸組 の施工が完了するまでに、間仕切、天井の下地軸組の施 エに携わる大工職以外の各職種がそれぞれの工事に介入 する頻度を示したものである。間仕切、天井下地軸組の 殆どは、大工職の職人で施工されている。配管・配線類 工事は、間仕切の下地軸組の施工と交錯することが多く、

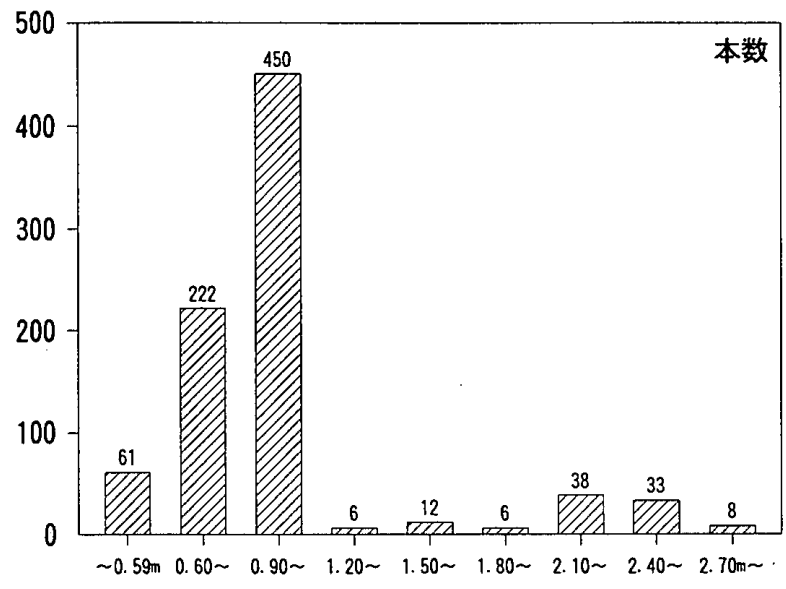

図 9 軸組を搆成する部材の長さの内訳 （間仕切軸組、調查IV)

間仕切

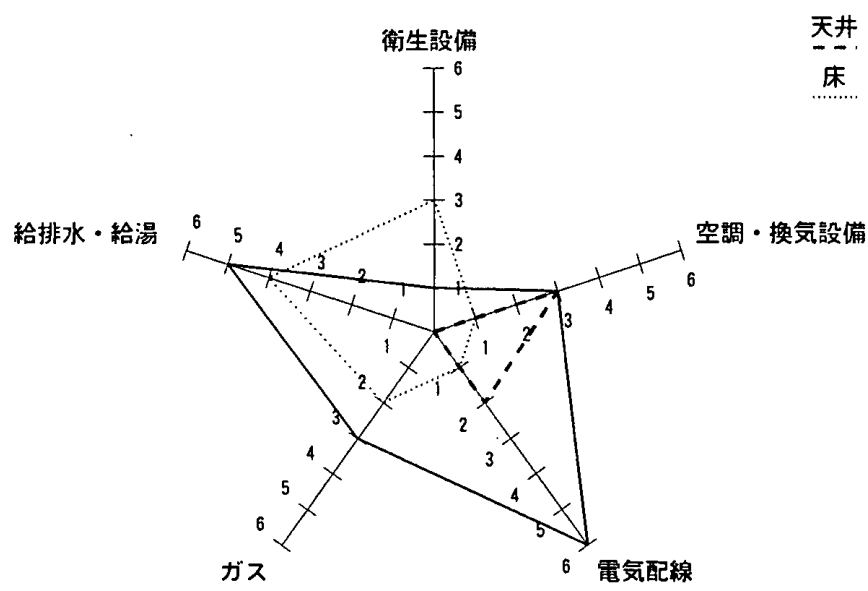

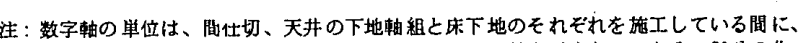

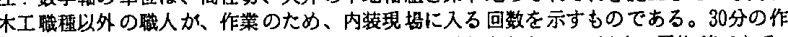
栄時間を一回と設定した。因中の回数は本研究で刘象とした $5 つ$ の铎查の平均值である (小数以下を省略(切り搭て))。

図10内装施工と配管・配線。設備機器工事等とのかか わり（調査 $1 \sim v$ の平均）

天井の下地軸組は主に、空調・換気設備と関わっている。 現状では、集合住宅の天井の施工量は一般に少なく、天 井の木製下地軸組と関わっている配管・配線・設備機器 類が多くない設計となっているため、配管・配線・設備 機器などの工事が天井の施工性に与える影響はそれほど 大きくない。しかし、今後、導入される設備が增加し、 集合住宅の天井の施工量が增えると、天井軸組と配管・ 配線・設備機器類との関わりが施工上のネックになる可 能性が高い。将来の涩化に対応するためにも、現行の天 井軸組構法のもつ問題点を検討しておく必要があろう。

5.まとめ

今回の調查結果を比較・分析した結果、朴製軸組間仕切 と天井の施工特性について、以下のようにまとめること ができる。 
集合住宅の間仕切の下地軸組は、内装下地の施工にか かる工数のかなりの部分（工数の 6 割）を占めている。 一つの理由は、間仕切軸組の施工量が大きいことであり、 今回の調查の場合は間仕切、天井軸組、休の 3 部位の合 計の 46.9\%を間仕切が占めている。いま一つの理由は、 多くの配管・配線・設備機器と取り合うため、間仕切の 軸組の部材配置が複雑なことである(参考文献 1 を参照)。 集合住宅住戸平面の多様化、住宅供給方式の変化、また、 住生活レベルの向上に従う室内配管・配線量の增加によ って、間仕切軸組の工数は、今後、益々増えていく可能 性がある。間仕切の施工性を向上させることは、内装構 法全体の施工性を改善する上で、中心的な課題というこ とができる。

次に現行の木製軸組天井の施工性が比較的低いことが あげられる。天井下地軸組の施工効率は、間仕切軸組よ り低く、本研究の調查の場合は、天井軸組の面樻当たり の工数の平均は間仕切軸組の約 1.3 倍である。施工上の 支障を引き起す主な原因は、天井軸組の位置であると言 える。すなわち、高い場所で線状の水平部材を取り扱う ことが困難な作業であるためである。特に、部屋の広さ が軸組用部材の一本の長さを超えた場合は、途中で接続 することになるが、つなげた部材の撓みが大きいため、 持ち上げて職人一人で施工することが困難な作業となる。 また、できあがる軸組全体の撓みをおさめ、平面性を確 保するために、補強のための野縁受と吊木を設置しなけ ればならない。その他に、棈造躯体の梁も、天井軸組を 組む作業の施工性に影響を与えている。特に設計天井高 さが現場で梁の寸法と合わなかったり、躯体構造の精度 が低いときには、天井軸組の部材配置は職人の現場判断 に任せられることとなり、結果として、職人技能への要 求が厳しく、施工の質と効率を確保することが難しくな る。現状では、殆どの集合住宅が住戸面積のこく一部に 下地軸組を組む天井構法を用いているが、今後は、新し い筀調設備・換気設備の導入などにより、天井の施工量 が增える傾向にあると考えられる。上述のような現行の 木製軸組天井構法が間仕切構法に比へて問題点を抱えて いることは益々明瞭化すると予測される。

\section{6.おわりに}

現在一般的に行われている集合住宅の間仕切、天井の 木製下地軸組構法は、多種多椂な施工環境や室内の配管 ・配線・設備機器に対応する高い適応力をもっている。 これらの長所を維持することを前提として、現行の間仕 切の施工効率を改善するとともに、天井の下地軸組の構 成を検討することが、今後の内装構法にとって重要であ る。
本調查を行うにあたり、御協力下さった住宅・都市整 備公団、青木建設、熊谷組、東急建設、東急工建の方々 及び阿部尚子さん（当時東京都立大学大学院生）に深く 感謝します。

注：

1)：但し、モれらの多くは人工を日単位や時間単位でとらえるものが多く 本畧文のような詳細なデータを眍錄しているものは少ない。育考文献 4)、5)、9)などは詳細なデータをとっているが、調查の目的が 異なってろ。

2) : 考文献 1のP115の图14、P116の图15を参照。

参考文献

1）王 英健、深尾精一：集合住宅の木製軸組間仕切の施工性に関す 万調查研究、日本建築学会計画系論文集 No. 457, pp. 111 116, 1994, 3 2) 中村晋樹、安藤正雄、深尾精一、小島浩土：集合住宅の内部掅成

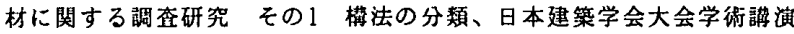
梗概集 (北陸) 昭和 58 年 9 月、pp. 1607 1608

3）小忽浩土、深尾精一、安藤正雄、中村案樹：多様な間取りをもつ 集合住宅の内装工事に関する調査研究、日本建築学会大会学䚘棓演梗 概集(関果) 昭和 59 年 10 月、pp. 1375 1376

4）高橋 暁、小島浩土、媣尾精一、安藤正雄：集合住宅の内部模成 材に関する調烃研究 その4 在来梅法内装工事における木工束の分析、 日本建築学会大会学術講演梗概集(東海) 昭和60年10月、pp. 451 452 5）小岛浩士、高橋 暁、梁尾精一、安藤正雄：集合住宅の内部椛成 材に関する調查研究 その5 間仕切壁棈法におけるパネルの効果につ いて、日本建築学会大会学術誨演梗概集(東海) 昭和 60 年 10 月、pp. 453 $\sim 454$

6）中村落樹、安藤正雄、藤摆好一、小岛浩士、高橋 暁、深尾辕一

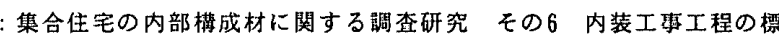
準化に関する考察、日本建築学会大会学術請演梗概集 (果海) 昭和 60 年 10月、pp. $455 \sim 456$

7) 高楅 暁、深尾精一、安藤正雄、戸倉健太郎：集合住宅の内部桡 成材に関する調查研究 その9 閵仕切壁槽法の施工性比較、日本建筑

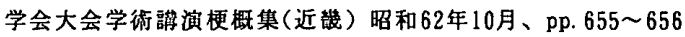

8）竹之内崇昌、深尾精一：集合住宅の内部捧成材に関する調查研究

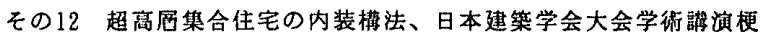
概集（九州）1989年10月、pp. 667〜668

9）阿部尚子、深尾辕一、王 英健：集合住宅の内部構成材に関する 調查研究 その17 二重天井搆法の施工性について、日本建築学会大 会学術䛿浭概集 (東海)1994年9月、pp. 939 940

10）内田祥哉(監修)：構法計画ハンドブック、朝倉書店 p. 614

（1994年 9 月 8 日原稿受理，1995年 2 月15日採用決定） 